\title{
WHO CARES WHAT WE SPEAK: A CASE STUDY AT KGOŠI MAMPURU CORRECTIONAL FACILITY
}

DORAH RIAH MABULE

Department of Linguistics and Modern Languages, University of South Africa

(c) 2018 Dorah Riah Mabule

This is an open access article distributed under the Creative Commons Attribution-NonCommercial-NoDerivs license (http://creativecommons.org/licenses/by-nc-nd/3.0/)

DOI: $10.1515 /$ eras-2018-0001

\begin{abstract}
The aim of this article is to explore the dynamic of language choice and language use as well as to examine the effect of language policy on language attitudes in the Department of Correctional Services (DCS) with special reference to Pretoria Central Prison, now called Kgoši Mampuru Correctional facility where there is some resistance to the use of English as the only official language of business.

A case study was conducted at this facility to find out the language attitudes of the participants towards English as the only official language of business. A questionnaire was used to evoke the participants' attitudes and beliefs regarding the importance of the use of other official languages (indigenous languages which, like English, also have official status) in their daily lives. A total of 60 correctional services staff and 280 offenders took part in this research study. Interviews and observations were mainly carried out at the research site to triangulate the data. Only the findings from the 280 offenders will be reported in this article.

The findings of this research study show that the participants were keen to use their languages of choice and favoured the language functions of their indigenous languages. The findings suggest that the prevailing language attitudes were in contrast with the aims of language policy at DCS thus making the effect of language planning not to be realized.
\end{abstract}

Keywords: Language Choice, Language Use, Language Attitudes, Language Planning, Language Policy.

\section{INTRODUCTION}

This article focuses on the outcome of a study conducted between 2008 - 2009 on language attitudes, language choice and use at the Pretoria Central Prison now known as Kgoši Mampuru Correctional Service Facility. This facility is part of the South African Department of Correctional Service (DCS) and the community is diverse in terms of language, culture and religion.

Remember during the apartheid era most government documents were in Afrikaans (this is the language that was promoted then) and English. E.g. information would be written in Afrikaans followed by English below. People were forced by the apartheid system to use Afrikaans as a means of communication at DCS including this facility. Therefore, when South Africa gained freedom from apartheid system in 1994, it became imperative to include the bill of rights in the Constitution that will give people the rights to use their own languages.

According to the South African Constitution of 1996, every person has the right to language choice and use. These rights are enshrined in Chapter 2 of the Bill of Rights of the Constitution of the Republic of South Africa, 1996 (Act No. 108 of 1996) as well as in the South African national language policy. The rights read as follow: "Everyone can use the language and follow the culture or the religion that they choose."

The limited use of other South African languages at DCS creates a problem of communication amongst the inmates as well as the correctional service staff. The statement may be assumed as supporting the hypothesis below. 
The Sapir-Whorf Hypothesis on language reads as follows:

'Man is not free. Man is not great. He is bound. He is trapped. He does not necessarily say what he thinks. He does not even think freely. Cognitively he is a prisoner of the structure of his particular language"” (Fishman, 1985:137)

From the hypothesis above, one is able to deduce the fact that language or language choice is an inalienable right of all human beings.. It is clear that language use or choice does not come cheap as it can imprison or free an individual who is the user of a language.

Language attitudes play an important role in language development and language maintenance in multilingual societies. How language is viewed by its speakers and by other members of the society who speaks other languages could determine the fate of that language, meaning its status, maintenance, development and use.

Language attitudes arise when 'one social group comes into contact with the other groups possessing different languages and each group then develops ideas about the other group's language vis-à-vis its own' (Eastman, 1983:30).

Many researchers such as sociolinguists, social psychologists, anthropologists, educationists to name a few have researched extensively on this subject. They came up with different conclusions based on the people or community that they had researched. Language attitudes are regarded as the attitudes perceived either positively or negatively towards a particular language at a certain time.

The description of attitudes entails one's ability to assess language attitudes and/ or attitudes of the participants from the data gathered on language attitudes at this facility within a particular context (Eagly and Chaiken 2007). It can be assumed that the participants were somehow trapped or bound by the rules and regulations of the facility as far as language choice is concerned. Fishman and other researchers on language attitudes support the idea that man does not have a freedom of language choice. It can be at work, social gathering or even at an institution.

On the other hand, Fasold holds the view that language attitudes should not be restricted towards language alone but should be open to speakers of whatever language and society they live in (1984:148). Experts on language attitudes should make an effort to include language maintenance and language planning as they are changing all the time because of the economic situation of a country that may change for the better or the worse. This produces different language attitudes among its speakers or potential speakers.

When attitudes towards a certain language are negative, it is extremely difficult for any agency to effect change in the status of that language. In the case of the research study conducted at Kgoši Mampuru (when the study was done it was called Pretoria Central Prison) Correctional facility, mixed messages were received regarding language attitudes and language choice.

At the DCS, English is regarded as the language of business, meaning that other languages that have been elevated to the same status as English language are overlooked or not used. The DCS policy is clear about this even though the people inmates in this facility feel that their language rights had been violated. The limited use of other South African languages at the DCS created a problem of communication amongst the inmates as well as the correctional service staff.

Language attitudes may be important in implementing a language policy, but they are extremely difficult to measure because they are primarily veiled positions that are not easily recognizable. Fasold (1984:147) posits that, 'an attitude is an internal state of readiness, rather than observable response'. Any attempt at interpreting attitudes towards a particular language makes it slippery. It can be said that no single methodology is proven to be able to reveal language attitudes effectively and accurately. 
According to Bourhis (1984:174), language planning can be quite 'a controversial enterprise when it involves the promulgation of a single language as the only official language of a society' in this case of the Department of Correctional Services (DCS). This is a process that many nations have to undergo because of the need to have a common means of communication for the people, especially when they are from diverse ethnic and language backgrounds like at the Kgoši Mampuru Correctional facility.

The aim of this article is to examine the effect of language policy of the DCS towards the use of English as the only language of business at Kgoši Mampuru Correctional facility. There was some resistance to the DCS language policy on the use of only English as the official language of business.

\section{BACKGROUND}

\section{A brief history of the Pretoria Central Premises now called the Kgoši Mampuru Correctional facility}

There are six prisons in one premise built at different times. For clarity, the researcher will use the term prison just for the background study.

\section{First prison in Pretoria}

In 1858 building plans were drawn for the first prison in Pretoria. Nothing happened until 5 April 1865 when magistrate C Moll sentenced an Alexander Anderson to 12 months hard labor. There was no building and they made a compromise whereby Anderson was to build the prison himself and then he will get deduction on his sentence. He built this on the corner of Pretorius and Paul Kruger streets. This building was like the 'hartbeeshuis' type and not very 'safe'.

\section{Second prison in Pretoria}

On 3 March 1873 the Volksraad asked for a new prison building, which was approved. This was built on the corner of present Bosman and Visagie streets. (Later the building for the Munt was erected on the corner and presently the Cultural History Museum is situated in that building.) The west side of the premises was bordered by Potgieter street, and the south side near Minnaar street had houses for the wardens. The prison itself was in the north-eastern corner and from there up to the western border were gardens and the gallows - executions were done in public, especially on a Saturday morning, everyone was welcome to view this.

This prison had cells for white and black male offenders, the death row cells, cells for white and black female offenders and a cell for awaiting trial people. In 1893, ten (10) more cells were built.

The building was not strong and escapes were easily done. In 1894, the floors were made out of cement instead of slate stone to try and prevent all the successful escapes which occurred regularly and it was decided to build a bigger and safer prison. 


\section{Third prison in Pretoria}

The Anglo-Boer War of 1899 - 1902 stopped all plans to start with the new prison building. The site that they decided to build the prison on was far outside Pretoria in the veld and it was the south most point of Potgieter street.

In April 1902 they started with the surrounding wall. Tenders were needed to build certain buildings and the company that was awarded the tender was Brown \& Cottrill of Johannesburg in 1903. After four months nothing happened and the tender was revoked and was given to Maudsley company. After another setback, the tender was given to another company called Prentice \& Mackey in November 1904. The prison was finished in 1907. Between 1912 and 1938 the communal cells were changed into single cells.

In 2000 they started with changes in the prison - the old kitchen was replaced by a more modern complex, the old office and previous kitchen area were replaced by contact and non-contact visit area and by new offices. Every cell received a washbasin and toilet. The electricity wires on the outside of the walls were replaced and hidden (electricity was brought into the prison in the 1930s). The school section had modernized classrooms and a library was also built.

\section{Local prison}

Local prison was built in the early 1900's but after the Central prison was built. The main entrance was Potgieter street. The prison was slowly demolished and rebuilt since the 1970s. It took 17 years to rebuild because offenders were used for this job.

\section{Female prison}

The building was originally for awaiting trials and after a daring escape in 1979, the place was rebuilt to accommodate the political offenders and in 1996 the women offenders moved into this building. The women were at first in the new section next to central and from then to the present one.

\section{C-Max prison in Pretoria}

The maximum prison was built approximately in 1965/6. The executions were done in this prison from 1968 - 1989. Currently this prison holds the most notorious and ruthless offenders and those who are charged with treason.

\section{The problem and its setting}

The facility holds offenders from the whole country. This has created a unique system of communication because of the variety of languages that the offenders and the staff speak. The use and choice of a particular language created a situation whereby other offenders felt discriminated against. The accuracy of communication between the correctional services' officials and the offenders in the day-to-day communication within multicultural and multilingual community became an issue.

In the new South Africa, language is a communication tool that can establish either positive or negative language attitudes towards a particular language irrespective of its status. The Kgoši Mampuru Correctional facility is one of the largest correctional facilities in South Africa and due to changes in the political setting in the new South Africa, the facility has also 
undergone some changes regarding the issue of language policy. All the official languages are spoken at Kgoši Mampuru Correctional facility and other languages from other African countries where Portuguese and French are spoken. The problem of refugees also created a challenge for language use. Within the complex language milieu, a number of different languages and language varieties came to the fore.

\section{THE RESEARCH PROBLEM}

The Kgoši Mampuru Correctional facility deals with different languages and different cultures thus it makes it a point of contact for dialects or varieties within one given language, and sub-groups within one given culture. The existence of many languages in a facility implies the existence of many cultures. According to Edwards (1994:177) the interests and tension that exist between languages and cultures can be seen to be transparent in immigrantreceiving countries, especially to those states whose very origins are multi-ethnic and multicultural. South Africa is one of the immigrant-receiving countries and this became clear after its independence in 1994. The number of people migrating to the townships as well as immigrants who enter South Africa daily, legally or illegally has increased enormously. The social context of language evaluation is very important because language is the main instrument through which social interaction takes place.

A language attitude is more than an attitude towards a particular language since the language attitude reflects the attitude towards a particular cultural group. According to Webb (1985), language is the most important social polarizing factor, because of its closeness to society. Brown (1987:128) stresses the fact that language learning is part of a process of acculturation that requires a re-orientation and permeable, adaptable ego boundaries. Language attitudes form part of complex sets of attitudes, and they usually resist change.

According to Ryan and Olds (1985) there are three possible points of view from which language can be evaluated. Language evaluation could either reflect intrinsic linguistic inferiority or superiority, intrinsic aesthetic difference or social values and preferences.

The first possibility which is intrinsic inferiority or superiority, has been refuted because of empirical evidence that all languages and varieties of language are linguistically equal and also that the constitution of South Africa entrenches the status of all languages. No proof exists to support the notion of greater aesthetic beauty in a specific language. Judgements regarding the quality and prestige of certain language varieties depend upon knowledge of social connotations of a variety of its speakers (Ryan and Olds: 1985).

Studies of people's language attitudes provide insight into the importance of language as symbol of membership of a certain cultural or ethnic group. Trudgill (1984:131) points out that a language is a crucial factor that determines group identification and solidarity and leads to greater emphasis on differences between two or more language varieties when one language group is threatened by another.

Language attitudes could play an important role in the motivation of people. The problem of highly motivated people is that they tend to be assimilated thus rejecting their own community as they identify themselves more with the language that they have been motivated to use (Roos:1991). After this investigation, a conclusion will be drawn and possible solutions will be suggested.

Information was gathered through questionnaires, interviews and observations of the participants' language use. The fieldwork took three months in 2007. The information was gathered at the site (Kgoši Mampuru Correctional facility) and at the ministry (the National Department of Correctional Services) where permissions and ethical clearances are granted. 
Using case studies allows 'an investigation to retain the holistic and meaningful characteristics of real-life events in context (Yin, 1994:3). To ensure reliability, the procedure for data collection and analysis was closely documented in operational terms to establish chain of evidence, where there are clear links between the research questions asked, the data collected and the conclusions drawn. This was done in order to minimize biasness in interpreting results. Conclusions made were based mostly on questionnaire results which were subjected to explanations to find out if the evidence was coming closer together to increase internal validity (Yin, 1994:35). The results generalized only settings that are similar to the Kgoši Mampuru Correctional facility.

\section{Participants}

A total of 280 prison offenders and 60 correctional officers were used. This article is based only on the responses of the prison offenders on language attitudes at this Correctional facility. The Kgoši Mampuru Correctional facility is a multilingual and multicultural facility where all the South African languages including the languages from the neighboring countries. The majority of the participants were South Africans who are from different language groups. Proficiency in English which is the language used for official business at this facility, depended on the educational background of the participants. The home language of the participants is indicated in the table below:

\begin{tabular}{|l|l|l|}
\hline Language & Frequency & Percentage \\
\hline Afrikaans & 11 & $3.9 \%$ \\
\hline English & 8 & $2.9 \%$ \\
\hline Isixhosa & 25 & $8.9 \%$ \\
\hline Isizulu & 80 & $28.6 \%$ \\
\hline Nothern Sotho & 51 & $18.2 \%$ \\
\hline Sesotho & 15 & $5.4 \%$ \\
\hline Setswana & 31 & $11.1 \%$ \\
\hline Tshivenda & 4 & $1.4 \%$ \\
\hline Xitsonga & 31 & $11.1 \%$ \\
\hline Others & 24 & $8.4 \%$ \\
\hline Total & 280 & $100 \%$ \\
\hline
\end{tabular}

Table 1: Home Language

Language question was used to establish how many indigenous languages were there in this prison. The question was asked because the prison officials mentioned earlier that they use English to communicate with the prison offenders as it was easier. If one looks at the table above, one realises that only a small percentage mentioned English as their home language. This can be interpreted as $37.5 \%$ of the Nguni group are at a disadvantage as far as the use of their languages are concerned as well as $34.7 \%$ of the Sotho group.

There is a possibility of using another language alongside English and Afrikaans as the language of communication. The language policy of the DCS prefers English over the indigenous languages which the Constitution of the Republic of South Africa has elevated to the same level as English and Afrikaans. The historical period of South Africa and the issue of compromise has led to government preferring the use of English as the business language in all government departments. 


\begin{tabular}{|l|l|l|}
\hline Education & Frequency & Percentage \\
\hline No response & 13 & $4.6 \%$ \\
\hline Primary education & 62 & $22.1 \%$ \\
\hline Secondary education & 126 & $45 \%$ \\
\hline Tertiary education & 79 & $28.2 \%$ \\
\hline Total & 280 & $100 \%$ \\
\hline
\end{tabular}

Table 2: Education background of the offenders

Most of the respondents have secondary (45\%) and tertiary (28.2) education. This is an indication that respondents are able to read and write. They were able to respond to the questionnaire distributed to them. The interpretation of this question can support the issue of language preference which some of the respondents indicated that they prefer to communicate in their language of choice of which is not the case. Language proficiency in English is still a challenge to many offenders as it is indicated in table 1 on home languages.

The table that follows indicate language preference and this is the core of the problem that contrasict the sentiments of the prison offenders irrespective of prefering English over their languages of choice for use for official business.

\begin{tabular}{|l|l|l|}
\hline $\begin{array}{l}\text { Language } \\
\text { preference }\end{array}$ & Frequency & Percentage \\
\hline Afrikaans & 5 & $1.8 \%$ \\
\hline English & 104 & $37.1 \%$ \\
\hline isiXhosa & 8 & $2.9 \%$ \\
\hline isiZulu & 71 & $25.4 \%$ \\
\hline Northern Sotho & 24 & $8.6 \%$ \\
\hline Sesotho & 16 & $5.7 \%$ \\
\hline Setswana & 16 & $5.7 \%$ \\
\hline Xitsonga & 12 & $4.3 \%$ \\
\hline Any & 4 & $1.5 \%$ \\
\hline Others & 13 & $4.8 \%$ \\
\hline Total & 280 & $100 \%$ \\
\hline
\end{tabular}

Table 3: Language preference

The majority of the respondents $(37.1 \%)$ prefer to use English even though there are few English mother tongue speakers. This is indicated under home language where only 8 (2.9\%) are English mother tongue speakers. The respondents regard English as the elite language as well as the language of power. English is regarded as a vehicle for horizontal and vertical mobility. This prison has foreign nationalities and different ethnic groups of South Africa. English is therefore used to facilitate easy communication. English is regarded as quick and easy to adapt in different situations. It said to promote social interaction and understanding in society.

\section{Questionnaires}

Questionnaires were used in the study to examine language attitudes. A questionnaire is one of many ways through which information can be obtained. A questionnaire is a research instrument consisting of a series of questions asked to individuals to obtain useful 
information regarding the topic being researched. A questionnaire is relatively economical, has the same questions for all subjects, and can ensure anonymity.

The questionnaire was in English owing to the fact that the Kgoši Mampuru Correctional facility is multilingual and multicultural society, even though the participants' home language was not English. Prison offenders had a certain level of understanding English. The researcher did not encounter any problems and the procedure went well. The researcher was also available to answer any questions that were problematic or could cause confusion.

The questionnaire was distributed to 280 multilingual participants at this facility and all the questionnaires were collected on site after completion.

\section{FINDINGS AND ASSUMPTIONS}

Prison offenders pointed out the importance of using English especially in prison. They mentioned to the researcher that without the basic knowledge of English, communication between inmates and DCS officials become a nightmare. Although they wished to have language choice, circumstances dictated which language to use and when. Some offenders had language attitudes towards the use of English as a business language. According to these offenders, different languages at this prison make it impossible to use the language of your choice. They regard the use of English language as a compromise in such a multilingual prison, where foreign languages such as French and Portuguese are found. Some of the prison offenders who were interviewed, felt that their language rights are always violated because they are incarcerated. The following are some of the assumptions linked to the findings of this research:

\section{English as an elite language}

English in the New South Africa is regarded as very important. This is confirmed by the fact that the prison community at large does not really see African languages as important like English although they have been elevated to the level of official languages. Many prison communities, comprised of offender strongly believe that English is capable of serving as a national language at all levels of governance. This is an indication of extraordinary admiration and inspiration of the mass.

According to Moyo (2000:152), "English remains powerful and it was seen by other researchers as having different kinds of power - colonial power to rule - power to influence, initiate and to cause change. Many believe that English has power to free oneself from poverty, starvation, oppression, ignorance, homelessness and other things in one's life.

An African language is looked down by the very same people who are the custodians of those languages. Crystal (1997:40) argues that "Blacks see English as a means of achieving an international voice, and uniting themselves with other Black communities". From Crystal's observation one is able to deduce that African languages are marginalized for not being developed to the level of English and Afrikaans. The owners of these languages had developed negative attitudes towards their languages thus excluding many black people from participating in national affairs.

The Constitution of the Republic of South Africa stipulates clearly that all languages have the same official status meaning they are equal. This is viewed as just lip service by the users of these languages, equity in terms of language practice in national affairs is impossible to achieve. According to UNESCO Working Document (1997:1) as cited in Mutasa (2003:298), "it is generally believed that the values, prestige and importance attached to a 
language are proportional to its perceived usefulness in various areas of activity." The document continues on the same page to say, "...it is the combined effect of a variety of socio-economic factors and of 'linguistic ecology' that conditions and shapes the functions and status of languages in multilingual contexts." In South Africa, English is used to perform more functions than any other language and it has gained more popularity amongst blacks especially after the fall of apartheid. It remains a powerful force to compete with and it is also viewed as passport to success. English remains as powerful as ever before as it gave the colonial regime to rule and govern black people. In DCS during Apartheid era, English and Afrikaans were both functioning at equal footing. Documentations and some legal proceedings were conducted in both languages irrespective of the victim or the perpetrator being a black person.

\section{English as a global language}

English is regarded as an international language that is neutral and it allows communication across linguistic and cultural borders. As much as it serves the purpose of global language, it also creates issues of discriminatory in the sense that other languages are now regarded as inferior in status and unintelligible to compete in global village. This is supported by Philip Seargeant and Elizabeth J. Erling's (2011: 261-262) research on English as a language of international development where they stated that the research findings is that English is now perceived as having global status.

\section{Societal and individual multilingualism as a resource for socio-economic development}

The research findings show a strong evidence of multilingualism in this correctional facility. Individuals and other members of this correctional facility community indicated that they are proficient in more than one language. This is an indication that African languages can be developed to the level of English and Afrikaans. According to Kashioki (1993:150), "Where multilingualism is consciously built into the country's language policy as the dominant principle, it has the likely consequence of broadening opportunities for more citizens to participate in national affairs". South Africa as a multilingual society should maintain multilingualism and also try strategies that can help in using multilingualism at national level.

\section{Language policy promotes nation building}

The research findings also indicate that the language policy is a preservation of linguistic and cultural heritage of mankind. The policy recognizes all languages, therefore, it is perceived as progressive and accommodative as it also upholds the linguistic human rights. Promotion of multilingualism is acknowledged by the respondents and it is seen as an important part of nation building. Linguistic diversity should be enforced and be promoted at workplaces in order to implement language policy.

\section{The current language policy is viewed as lacking the ability to be implemented}

The research findings indicated that although people view the language policy as one of the best language policy in the world, the issue of implementation is a real challenge. The government is reluctant to spend money on the development of African languages. They regard this as an expensive exercise even though the Apartheid government did that when 
they develop Afrikaans. The government does not see this as an investment but as an expense. During the twenty-three (23) years in power, very little or nothing has been done to promote and develop these languages.

\section{CONCLUSION}

From the analysis above, Afrikaans was labelled as the language of oppression and English as the language of liberation. The English language gained popularity amongst Africans irrespective of the language being a colonial language. It was regarded during that time and even now as the vehicle for ideologies of freedom and independence, and the symbol of liberal values and liberation (Kamwendo, 2006:56).

According to Alexander (1996:105), 'it is a well attested fact that throughout the continent of Africa, the majority of the people consider their languages to be unsuitable, at least at present, for what are to be considered the "higher function". Education is regarded as the base for mass participation and therefore education documents encourage the development of all the indigenous language for use in all spheres. The irony is that most speakers of African languages are opposed to the idea of education in their mother tongue. Mother tongue education has been highly politicized and it is viewed by many speakers of African languages as an attempt to be cut off from the business world, tertiary education or the international community by denying them access to English (Riana Roos Paola, 2001: 58 -59).

This attitude is part of a colonial inheritance evident in Africa that tends to see metropolitan or imported discourses as empowering in educational, business and political spheres. Most people choose to use the former colonial language than the indigenous language.

It has always been an issue that communications between prison offenders and prison officials are restricted by linguistic problems. Instructions that are given are sometimes misinterpreted by both the prison offenders and the prison officials. People are denied parole, bail or being jailed for the wrong reasons because of the language issue. 


\section{REFERENCES}

A draft language policy of Department of Correctional Services 2005.

Alexander, N. 1996. The African Renaissance, African languages and African education: with special reference to South Africa, In H. Ekkerhard Wolff (ed.) Tied tongues: The Africa Renaissance as a challenge for language planning. Munster: Lit, pp.21-37.

Bourhis, R.Y. 1984. The Charter of the French Language and cross-cultural communication in Montreal. In R.Y. Bourhis (ed) Conflict and Contradiction. Devon: Merlin Books.

Brown, H.D. 1987. Principles of Language Learning and Teaching. (2nd ed). Serbian: Prentice Hall.

Constitution of the Republic of South Africa, no. 108 of 1996.

Crystal, D. 1997. English as a global language. (2nd). New York: Cambridge University Press.

Eagly, A. H., \& Chaiken, S. (2005). Attitude research in the 21st century: The current state of knowledge. Mahwah, NJ, US: Lawrence Erlbaum Associates Publishers

Eastman, C.M. 1993. Language Planning: An Introduction. San Francisco: Chandler and Sharp.

Edwards, J. 1994. Multilingualism. London: Routledge.

Fasold , R., 1984. The sociolinguistics of society. Oxford: Blackwell.

Fasold, R., 1990. Sociolinguistics of language. Cambridge, MA: Blackwell

Fishman, J. A. 1985. The rise and fall of the ethnic revival: perspectives on language and ethnicity. Berlin \& New York: Mouton.

Kamwendo, G. E. 2006. No Easy Walk to Linguistic Freedom: A Critique of Language Planning During South Africa's First Decade of Democracy in Nordic Journal of African Studies 15(1): 53-70.

Moyo, D.T. 2000. The Impact of English in Zimbabwe: A Phenomenological and Historical Study 1980-1999. Unpublished Doctoral Thesis, University of Nebraska.

Mutasa, D. E. 2004. People Speak: Language Policy and Language Use in South Africa. Pretoria: Simba Guru Publishers.

Paola, Riana Roos. 2001. Pro-active language teacher education in multicultural society. Frankfurt am Main: Lang.

Roos, Riana. 1990. Language attitudes in the second language situation. In: Per Linguam, 6:2, 25-30

Sapir. E.1958. Culture, Language and Personality (ed. D.G. Mandelbaum) Berkerley, CA: University of California Press.

Seargeant, P. and Erling, E.J. 2011. The discourse of 'English as a language of international development': Policy assumptions and practical challenges. In Hywel Coleman *ed.) Dreams and Realities: Developng Countries and English Language. London: British Council. 255-270

Thomas,L and Wareing, S. (eds). 1999. Language, Society and Power: An introduction. London: Routledge.

UNESCO Working Document. 1997.

Yin, R.K. 1994. Case Study Research: Design and Methods (2nd ed). Thousand Oaks: Sage.Ramazanoglu, C., \& Holland, J. (2002). Feminist methodology: Challenges and choices. Sage. 